\title{
Marine Macrophyte Wrack Inputs and Dissolved Nutrients in Beach Sands
}

\author{
Jenifer E. Dugan • David M. Hubbard • \\ Henry M. Page • Joshua P. Schimel
}

Received: 22 February 2010 /Revised: 4 October 2010 / Accepted: 5 October 2010 / Published online: 26 January 2011

(C) The Author(s) 2011. This article is published with open access at Springerlink.com

\begin{abstract}
We investigated the role of sandy beaches in nearshore nutrient cycling by quantifying macrophyte wrack inputs and examining relationships between wrack accumulation and pore water nutrients during the summer dry season. Macrophyte inputs, primarily giant kelp Macrocystis pyrifera, exceeded $2.3 \mathrm{~kg} \mathrm{~m}^{-1}$ day $^{-1}$. Mean wrack biomass varied 100 -fold among beaches (range $=0.41$ to $46.43 \mathrm{~kg} \mathrm{~m}^{-1}$ ). Mean concentrations of dissolved inorganic nitrogen (DIN), primarily $\mathrm{NO}_{\mathrm{x}}{ }^{-}-\mathrm{N}$, and dissolved organic nitrogen (DON) in intertidal pore water varied significantly among beaches (ranges $=1$ to $6,553 \mu \mathrm{M}$ and 7 to $2,006 \mu \mathrm{M}$, respectively). Intertidal DIN and DON concentrations were significantly correlated with wrack biomass. Surf zone concentrations of DIN were also strongly correlated with wrack biomass and with intertidal DIN, suggesting export of nutrients from re-mineralized wrack. Our results suggest beach ecosystems can process and re-mineralize substantial organic inputs and accumulate dissolved nutrients, which are subsequently available to nearshore waters and primary producers.
\end{abstract}

Keywords Pore water. Sandy beach ecosystem . Ecosystem function · Intertidal $\cdot$ Re-mineralization $\cdot$ Wrack subsidy · Giant kelp · Surf zone · Nitrogen · Phosphorus

\footnotetext{
J. E. Dugan $(\bowtie) \cdot$ D. M. Hubbard $\cdot$ H. M. Page

Marine Science Institute, University of California,

Santa Barbara, CA 93106, USA

e-mail: j_dugan@lifesci.ucsb.edu

J. P. Schimel

Department of Ecology Evolution and Marine Biology,

University of California,

Santa Barbara, CA 93106, USA
}

\section{Introduction}

In coastal marine ecosystems, benthic and intertidal sediments or "marine soils" can play a major role in nearshore biogeochemical processes, particularly the decomposition of organic material and mineralization of nutrients (e.g., McCaffrey et al. 1980; Rauch and Denis 2008; Rowe et al. 1975). Re-mineralization processes in benthic sediments may be particularly important in coastal ecosystems that are characterized by episodic or low primary production; in these systems, nutrient release from benthic sediments could potentially provide a significant amount of dissolved nitrogen at critical times for sustaining productivity (see Boyle et al. 2004; Cowan et al. 1996; Rauch and Denis 2008; Rowe et al. 1975). The majority of existing studies of benthic mineralization have focused on fine muddy sediments with high organic content (e.g., Berelson et al. 1998; Boyer and Fong 2005; Boyle et al. 2004; Cowan et al. 1996). Nutrient cycling in coarse permeable sediments, including intertidal and continental shelf sands, has received considerably less attention (Rocha 2008). The assumption that the relatively low organic content generally present in these sediments (one to two orders of magnitude lower) is correlated with low biogeochemical activity, however, has been challenged by a number of recent studies (e.g., Anschutz et al. 2009; Boudreau et al. 2001; Huettel and Rusch 2000; Jahnke et al. 2005; Rocha 2008; Rusch et al. 2006), suggesting that this may represent an important oversight for nutrient dynamics of coastal and continental shelf ecosystems.

Located at the land-ocean margin, exposed sandy beaches make up $~ 70 \%$ of the world's open coasts (Bascom 1980). The idea that these widespread sandy intertidal ecosystems function in coastal nutrient cycling is not new. More than 60 years ago, Pearse et al. (1942) described 
beaches as "great digestive and incubating systems" largely because of their postulated role in nutrient re-mineralization and recycling. The ability of beach sands to filter large volumes of seawater demonstrated by McLachlan et al. (1985) and others that could in turn facilitate the decomposition and re-mineralization of organic matter supports this pioneering idea. There is growing recognition that quantification of the ecosystem function of beaches in coastal nutrient cycling has been largely neglected, and an increased understanding of the role of these permeable marine sediments is needed to evaluate coastal nutrient processing and re-mineralization of organic matter (Anschutz et al. 2009; Rauch and Denis 2008; Rauch et al. 2008).

Wave-exposed sandy beaches are a classic example of a subsidized ecosystem (e.g., Anderson and Polis 1999; Polis and Hurd 1996). In situ primary production is very low and communities of consumers are primarily supported by organic material imported from other ecosystems, including marine phytoplankton, macroalgae, seagrasses, and in some systems, carrion (e.g., McLachlan and Brown 2006; Colombini and Chelazzi 2003; Dugan et al. 2003; Heck et al. 2008; Inglis 1989; Wenner et al. 1987). The processing, decomposition and re-mineralization of these subsidies in beach sands may also make nutrients available to primary producers creating a potentially important feedback between exporting and recipient ecosystems. However, the question of nutrient export from these subsidized coastal ecosystems is just beginning to be examined (Avery et al. 2008; Maier and Pregnall 1990; Mateo et al. 2003).

Inputs of organic matter in the form of drift macrophytes that originate from nearshore reefs, kelp forests, and seagrass beds to sandy beaches can be substantial (Griffiths et al. 1983; Heck et al. 2008; Zobell 1971). For example, estimated annual inputs of up to $1,800 \mathrm{~kg}$ wet $\mathrm{wt} \mathrm{m}^{-1}$ of shoreline have been reported for kelps (Griffiths and Stenton-Dozey 1981; Koop et al. 1982). Spatial and temporal variability of these inputs and standing stocks can also be high in response to both environmental and anthropogenic factors (e.g., Dugan et al. 2003; Dugan et al. 2008; Orr et al. 2005; Revell et al. 2011).

Giant kelp, Macrocystis pyrifera, is a major component of the macrophyte subsidies that strand on sandy beaches in southern California (Dugan et al. 2003; Lastra et al. 2008) where inputs have been estimated to exceed $450 \mathrm{~kg}$ wet wt $\mathrm{m}^{-1}$ year $^{-1}$ (Hayes 1974). This fast growing extremely productive brown alga can form large forests on rocky reefs (Mann 2000; Reed et al. 2008). Net primary production of $M$. pyrifera is high (up to $2.3 \mathrm{~kg}$ dry mass $\mathrm{m}^{-2}$ year ${ }^{-1}$ ) and biomass of a kelp forest can turn over as many as seven times annually (Reed et al. 2008). Much of the large amount of organic material produced by kelp forests is exported to other habitats, as waves and surf break up the floating canopy and detach entire plants from the reef. As a result, floating rafts of drift kelp can be very abundant (39,000 to 348,000 rafts) in the Southern California Bight, and the majority of these are deposited on sandy beaches (Hobday 2000).

The possible fates of these large subsidies of drift macrophytes or wrack on sandy beaches include ingestion and break down by intertidal invertebrate consumers as well as burial and decomposition. When abundant, beach invertebrates can rapidly consume a high proportion of the wrack (Griffiths et al. 1983; Lastra et al. 2008). Following processing by invertebrates, particulates and nutrients from wrack infiltrate porous intertidal sand through the regular action of tides and waves. Particulates from degraded macrophyte wrack, as well as wave-delivered phytoplankton, can then accumulate in the subaerial water table of the beach where the carbon and nutrients are re-mineralized through microbial processes (e.g., Koop et al. 1982).

In regions that support kelp forests and other highly productive nearshore macrophytes, large amounts of these macrophytes are exported to intertidal consumers and microbial communities on sandy beaches. This creates a unique combination of high organic inputs and permeable sediments subject to regular tide and wave action that could result in rapid re-mineralization and nutrient cycling and the accumulation, as well as potential for export, of wrackderived nutrients from this subsidized ecosystem to nearshore waters. To explore the function and potential significance of these beach ecosystems in intertidal and nearshore nutrient cycling, we investigated the magnitude of inputs and the effects of organic subsidies exported by coastal reefs and kelp forests to the permeable intertidal sediments of sandy beaches on the concentrations and potential export of dissolved nutrients from wave-exposed intertidal sands.

\section{Methods}

Sampling Design and Study Sites

To examine the magnitude of marine subsidies and the potential effects on dissolved nutrients in intertidal pore water of sandy beaches, we (1) measured inputs of macrophyte wrack over time on a typical beach, (2) quantified the cover and standing crop of wrack for 10 beaches that differed in wrack abundance, and (3) explored relationships between concentrations of dissolved nitrogen and phosphate in intertidal pore water and surf zone water, and the abundance of macrophyte wrack for those beaches.

The study area, located along the mainland coast of the Santa Barbara Channel, has a Mediterranean climate with peak rainfall in the winter between December and March and generally rainless summers. Tides are mixed semi- 
diurnal and microtidal. To explore relationships between wrack inputs and pore water nutrient concentrations, we sampled 10 exposed sandy beaches that differed in proximity to kelp forests, the principal source of drift macrophytes to these beaches along $65 \mathrm{~km}$ of coastline (Fig. 1). The study beaches can be classified as intermediate in morphodynamic type as is typical of the region (Dugan et al. 2003) with average sand grain size at the water table outcrop ranging from 0.161 to $0.246 \mathrm{~mm}$ (mean= $0.207 \mathrm{~mm}$ ) during the surveys. Beach widths (unsaturated sand-landward limit to the water table outcrop) ranged from $29 \mathrm{~m}$ to $50 \mathrm{~m}$ and intertidal slopes ranged from $2.5^{\circ}$ to $5.3^{\circ}$ among beaches during sampling. Several of the study beaches were located on soft bedrock platforms backed by coastal bluffs (Isla Vista Beach, South Campus Beach, East Campus Beach, Arroyo Burro Beach) (Fig. 1). Four of the beaches were located near canyon mouths with seasonal streams (Gaviota State Beach, Refugio State Beach, El Capitan State Beach, Haskell's Beach, and Arroyo Burro Beach). Two of the beaches were backed by urbanized flood plain or marsh habitat (Santa Claus Lane and Carpinteria City Beach). One of the study beaches was regularly groomed to remove macrophyte wrack (Carpinteria City Beach).

\section{Estimated Input of Macrophyte Wrack}

To estimate the potential input rate of drift macrophytes, we measured and removed drift macrophyte wrack on one of the study beaches, South Campus beach, every 3 days for 51 days in July/August 2002. Four randomly selected 24$\mathrm{m}$-wide plots were initially cleared of surface and buried wrack by hand on July 9th. Subsequently, all wrack that accumulated between the sea bluff and the high swash level was collected by hand, categorized by taxon and type

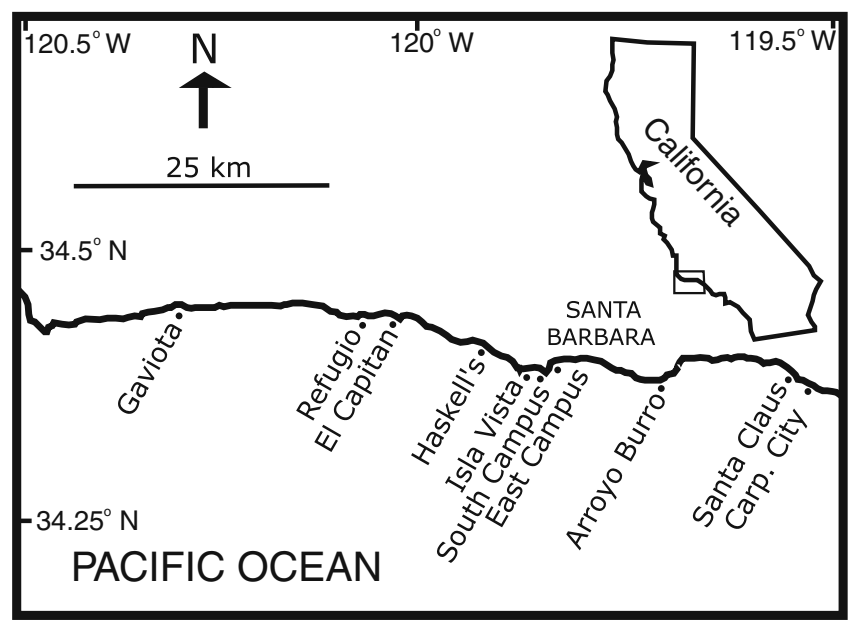

Fig. 1 Locations of the study beaches on the Santa Barbara Channel coast (fresh, dry), weighed to the nearest $100 \mathrm{~g}$, and removed every 3 days. Net input for each 3-day period was estimated from the mean biomass of fresh algae for the four plots. These biomass values represented net input for each 3-day period after loss to invertebrate consumers, such as talitrid amphipods.

\section{Field Comparisons}

To investigate relationships between the composition, biomass, and cover of macrophyte wrack and the concentrations of dissolved nutrients in pore water, we sampled the 10 study beaches during low tides in the late summer of 2003, 5 months after the last rainfall event. Although no information on groundwater was collected or available, the direct influence of terrestrial freshwater runoff and groundwater on intertidal pore water was generally expected to be reduced at this time of year in the study area. Beaches in the study region generally reach peak seasonal sand accumulation and volumes by late summer (Revell et al. 2011). On each beach, we established three transects extending from the landward boundary of the beach (the lowest edge of terrestrial vegetation or the base of the sea bluff) to the swash level. Distances between transects were randomly selected. When possible, we sampled an area of the beach with a natural landward boundary and measurable dry sand zone above the high tide strand or drift line.

We estimated the cover, depth, composition, and standing stock of macrophyte wrack on each of the three transects (see above) using a line intercept method. The taxa or species, cover (as length), and maximum depth of all drift macrophytes of $0.01 \mathrm{~m}$ or more in width that intersected the transect line were measured. The total width of wrack encountered was summed for each transect and a mean of wrack cover was calculated for each beach. The biomass of wrack was measured on each transect by collecting, categorizing, and weighing all wrack within a 1-m-wide belt transect that extended from the landward limit of the beach to the high swash limit. Wrack was shaken to remove sand and wet weights of each wrack type or species were measured with a spring balance to the nearest $10 \mathrm{~g}$ in the field. Wrack cover and biomass were expressed per meter of the shoreline (meters or kilograms $\mathrm{m}^{-1}$, respectively) to describe a vertical meter-wide strip of intertidal from the high to the low tide zone. This approach is suggested for measurements of biomass, cover, and other parameters in sandy beach ecosystems by McLachlan and Brown (2006) to enable comparisons among beaches with different intertidal widths, as sampled in this study, and among different tide, wave, and profile conditions at an individual beach.

Pore water samples were generally collected from three intertidal levels [high tide strand or drift line (HTS), mid- 
beach (Mid), and high swash level (HSL)] on each of the three transects sampled for macrophyte wrack. At each level, a pit was excavated with a spade to a depth where water filled the bottom of the excavation. Interstitial water samples of $50 \mathrm{ml}$ were collected with a plastic syringe from each excavation then immediately filtered (Whatman GF/F) into clean $20-\mathrm{ml}$ scintillation vials. It should be noted that water samples were not collected in an oxygen-free environment which may have caused the underestimation of phosphate concentrations. Water samples were also collected in the shallow surf zone immediately seaward of each transect and filtered as above. Water samples were transported to the laboratory on ice and stored frozen until analysis. Salinity of pore water and surf zone water $( \pm 1)$ samples was measured with a temperature-compensated refractometer (American Optical).

Concentrations of $\mathrm{NH}_{4}{ }^{+}-\mathrm{N}, \mathrm{NO}_{3}{ }^{-}-\mathrm{N}, \mathrm{NO}_{2}{ }^{-}-\mathrm{N}$, and $\mathrm{PO}_{4}{ }^{-} \mathrm{P}$ in pore water samples were determined by flowinjection analysis (Johnson et al. 1985) at the University of California, Santa Barbara Marine Science Institute Analytical Laboratory. $\mathrm{NO}_{2}{ }^{-}-\mathrm{N}$ concentrations, typically $<1.0 \mu \mathrm{M}$, were combined with $\mathrm{NO}_{3}{ }^{-}-\mathrm{N}$ (hereafter $\mathrm{NO}_{\mathrm{x}}^{-}{ }^{-} \mathrm{N}$ ). Dissolved organic nitrogen was analyzed by a persulfate digestion method (Doyle et al. 2004).

The effects of study beach and sampling level on wrack standing stock (biomass) and concentrations of $\mathrm{NO}_{3}{ }^{-} \mathrm{N}$ and $\mathrm{NH}_{4}{ }^{+}-\mathrm{N}$, total DIN, DON, and $\mathrm{PO}_{4}{ }^{-}-\mathrm{P}$ in pore water samples were evaluated using two-way and one-way analysis of variance (ANOVA) on data that were $\log (x+1)$ transformed to reduce heteroscedasticity. OLS regression analyses were used to examine relationships between nutrient concentrations and wrack biomass.

\section{Results}

Input of Macrophyte Wrack

During the 51 days of our drift macrophyte input study, a total of $>11,000 \mathrm{~kg}$ (wet weight) of macrophyte wrack was removed by hand from the four plots at the South Campus study beach (including the initial clearing on July 9). The measured input of fresh marine macrophytes to the beach during the study period averaged $1.7 \mathrm{~kg}$ wet $\mathrm{wt} \mathrm{m}^{-1}$ day $^{-1}( \pm 0.96$, std. dev., also reported for subsequent means) and varied over an order of magnitude ( 0.1 to $5.6 \mathrm{~kg}$ wet wt $\mathrm{m}^{-1}$ day $^{-1}$ ) among sampling dates (Fig. 2).

Freshly deposited wrack consisted primarily of several species of brown macroalgae and the surfgrass, Phyllospadix spp. Among the brown macroalgae, input rates of giant kelp, M. pyrifera, were highest, ranging from 0.03 to $4.4 \mathrm{~kg}$ wet wt m${ }^{-1} \mathrm{day}^{-1}$ (mean $=0.9 \pm$
$0.61 \mathrm{kgmeanwet} \mathrm{wt}^{-1}$ day $^{-1}$; Fig. 2). Input rates of feather boa kelp, Egregia menziesii, were nearly an order of magnitude lower (range $=0.0$ to $0.4 \mathrm{~kg}$ wet $\mathrm{wt} \mathrm{m}^{-1}$ day $^{-1}$, mean $=0.1 \pm 0.08 \mathrm{~kg}$ wet $\mathrm{wt} \mathrm{m}^{-1} \mathrm{day}^{-1}$ ) (Fig. 2). The combined inputs of the other brown macroalgal species (Cystoseira, Sargassum, Laminaria) were considerably lower (range $=0.0$ to $0.2 \mathrm{~kg}$ wet $\mathrm{wt} \mathrm{m} \mathrm{m}^{-1} \mathrm{day}^{-1}$, mean $=0.02 \pm$ $0.02 \mathrm{~kg}$ wet wt $\mathrm{m}^{-1}$ day $^{-1}$ ). Surfgrass, Phyllospadix spp., was the second most abundant component of wrack, with a net input of about half that of giant kelp (range $=0.04$ to $2.0 \mathrm{~kg}$ wet wt m $\mathrm{may}^{-1}$, mean $=0.5 \pm$ $0.36 \mathrm{~kg}$ wet wt $\mathrm{m}^{-1}$ day $^{-1}$ ) (Fig. 2).

Over our study period, which experienced calm sea conditions, we estimated a net input rate for marine macrophyte wrack of $1.7 \mathrm{~kg} \mathrm{~m}^{-1}$ day $^{-1}$, which yields an estimated total net input of $620 \mathrm{~kg} \mathrm{~m}^{-1} \mathrm{year}^{-1}$. For the dominant wrack species, $M$. pyrifera, the measured net input rate of $0.9 \mathrm{~kg}$ wet wt m${ }^{-1}$ day $^{-1}$ ( $329 \mathrm{~kg}$ wet wt $\mathrm{m}^{-1}$ year $^{-1}$ ) does not account for feeding by invertebrate consumers, many of which prefer this species of macroalgae (Lastra et al. 2008). Using an estimated feeding rate for the abundant talitrid amphipod populations at the study beach of $0.6 \mathrm{~kg}$ wet wt m${ }^{-1}$ day $^{-1}$ reported by Lastra et al. (2008), we calculated adjusted input rates for M. pyrifera of $1.5 \mathrm{~kg}$ wet wt m $\mathrm{m}^{-1}$ day $^{-1}$ yielding an estimated annual input rate of $548 \mathrm{~kg}^{-1}$ wet $\mathrm{wt} \mathrm{m}^{-1}$ year $^{-1}$. This estimate can be used to adjust the total estimated annual marine wrack input up to $840 \mathrm{~kg}$ wet wt $\mathrm{m}^{-1}$ year $^{-1}$ for the study area.

Standing Stock of Macrophyte Wrack on the Study Beaches

The standing stock of marine macrophyte wrack (as wet biomass) varied significantly (one-way ANOVA, $F=5.924$, $d f=9, p<0.001)$ and over two orders of magnitude among the 10 study beaches with mean values ranging from 0.41 to $46.43 \mathrm{~kg} \mathrm{~m}^{-1}$ (Fig. 3). Biomass was lowest at the groomed beach, Carpinteria City Beach. Mean values for the cover of macrophyte wrack varied by more than an order of magnitude across the study beaches, ranging from 0.24 to $5.68 \mathrm{~m}^{2} \mathrm{~m}^{-1}$ of shoreline, also lowest at the groomed beach. The mean volume of wrack (cover $\times$ depth) was positively correlated with the mean biomass of wrack $\left(r^{2}=0.511, n=10, p<0.05\right)$.

Brown algal material (including blades, stipes, holdfasts, and floats) comprised $50 \%$ or more of the total wrack biomass at five of the study beaches. The total mean standing stock of brown algae varied significantly among the study beaches (one-way ANOVA, $F=4.658, d f=9, p=$ 0.002 ) with mean values ranging from 0.25 to $14.01 \mathrm{~kg} \mathrm{~m}^{-1}$ of shoreline. Giant kelp, M. pyrifera, was an important component of the brown macroalgal wrack composing more than $50 \%$ of that biomass at eight of the beaches, averaging $74 \%$. The standing stock of $M$. pyrifera alone 
Fig. 2 Estimated mean inputs for 3 days ( +1 std. dev., $n=4)$ for the major types of macrophyte wrack deposited on the eastern portion of the South Campus study beach for July-August 2002

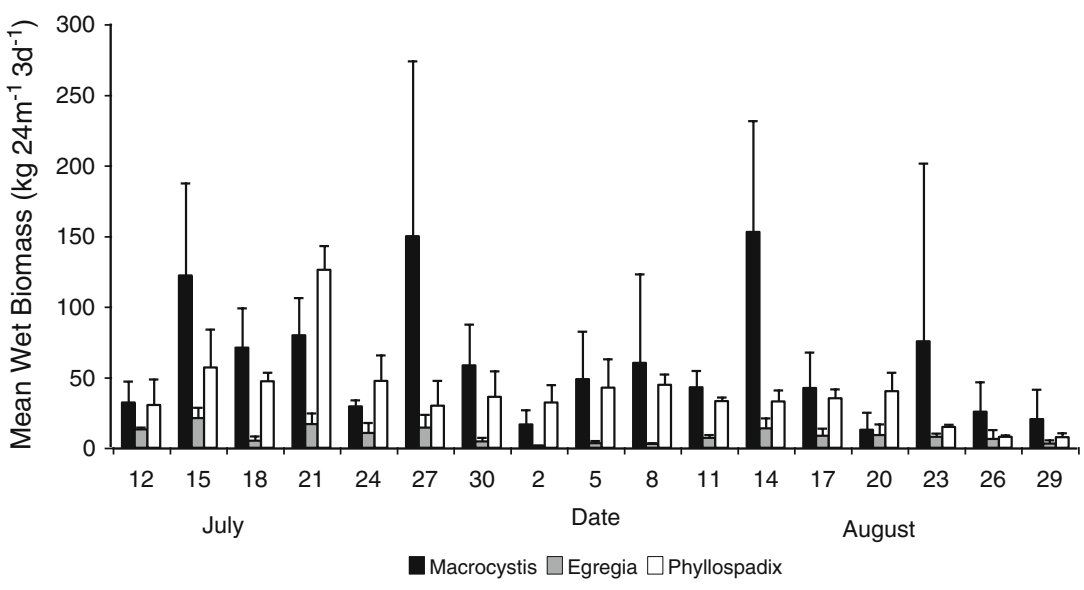

also varied significantly among study beaches (one-way ANOVA, $F=3.977, d f=9, p=0.005$ ) ranging from 0.21 to $8.50 \mathrm{~kg} \mathrm{~m}^{-1}$ of shoreline. Surfgrass, Phyllospadix spp., wrack comprised $50 \%$ or more of the total biomass at four beaches and standing stock varied significantly among beaches (one-way ANOVA, $F=5.246, d f=9, p=0.001$ ) ranging from $<0.01$ to $31.33 \mathrm{~kg} \mathrm{~m}^{-1}$ of shoreline.

\section{Intertidal Pore Water and Surf Zone Water}

The salinity of intertidal pore water ranged from 8 to 35 ; however, at most of the study beaches, the salinity of intertidal pore water was similar or equal to that of surf zone water (34) suggesting the relatively low influence of freshwater runoff or groundwater during the study period at these sites. However, at one of the study beaches (Santa Claus Lane), pore water in the sampling stations at the HTS

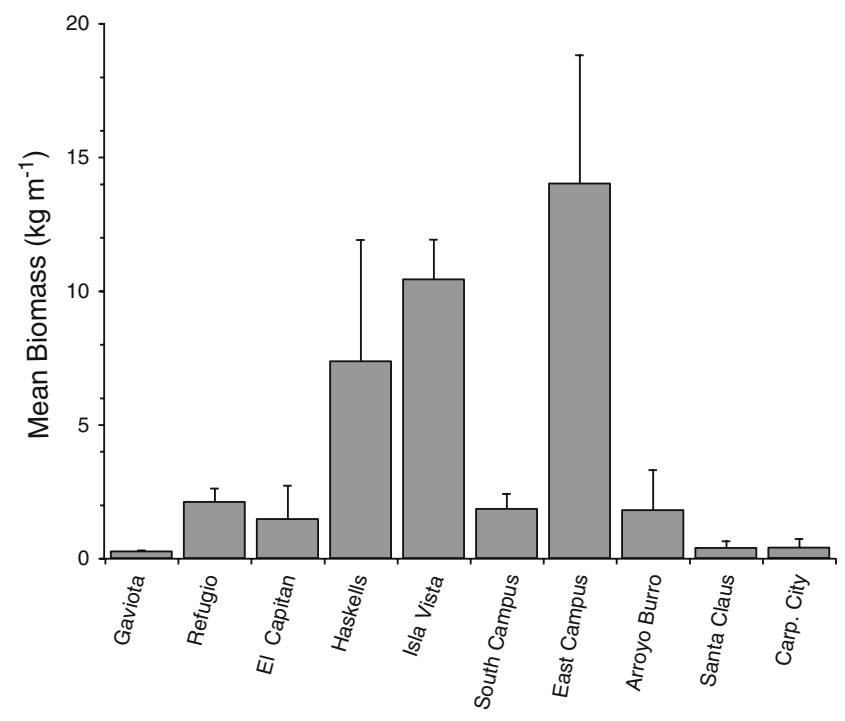

Fig. 3 Mean standing stock of brown macroalgal wrack expressed as wet $\mathrm{kg} \mathrm{m}^{-1}(+1$ std. err., $n=3)$ for the 10 study beaches in August 2003 was consistently brackish (10 to 15$)$ indicating contributions of fresher groundwater from terrestrial sources.

\section{Dissolved Nutrients}

Mean concentrations of total DIN in intertidal pore water varied over three orders of magnitude ( 1 to $6,553 \mu \mathrm{M}$ ) among beaches, exceeding $300 \mu \mathrm{M}$ at five beaches and $1,000 \mu \mathrm{M}$ at two beaches (Fig. 4). The principal $\mathrm{N}$ species found in intertidal pore water was $\mathrm{NO}_{\mathrm{x}}^{-}{ }^{-} \mathrm{N}$ (primarily $\mathrm{NO}_{3}{ }^{-}$), with concentrations ranging over four orders of magnitude $(0.05$ to $1,427 \mu \mathrm{M})$ among beaches. Ammonium concentrations were generally $<10 \mu \mathrm{M}$. However, at two beaches (Isla Vista and East Campus) with very high wrack biomass, ammonium concentrations exceeded 1,000 $\mu \mathrm{M}$, with the highest value $(10,744 \mu \mathrm{M})$ recorded in a sample from East Campus Beach at a sampling level with black anoxic sand. Although two-way analyses of variance indicated that concentrations of inorganic nitrogen species in pore water varied significantly with site and with sample level, there were significant site $\times$ sample level interactions present in every comparison (Table 1). In one-way comparisons, the concentrations of $\mathrm{NO}_{\mathrm{x}}{ }^{-} \mathrm{N}, \mathrm{NH}_{4}{ }^{+}-\mathrm{N}$, and total DIN in pore water varied significantly among beaches at most of the intertidal levels sampled (Table 2). In surf zone water, the concentrations of $\mathrm{NH}_{4}{ }^{+}-\mathrm{N}$ but not $\mathrm{NO}_{\mathrm{x}}{ }^{-} \mathrm{-N}$ or total DIN differed significantly among the study beaches (Table 2 ).

The concentrations of DIN, $\mathrm{NO}_{\mathrm{x}}{ }^{-}-\mathrm{N}$, and $\mathrm{NH}_{4}{ }^{+}-\mathrm{N}$ in pore water varied significantly among sampling levels at all beaches (Table 3). The highest $\mathrm{NO}_{\mathrm{x}}{ }^{-}-\mathrm{N}$ and DIN concentrations were generally found in samples collected from the high tide strand line (HTS) or drift line where wrack accumulates (Fig. 5a). The highest ammonium concentrations were generally found in samples collected lower on the beach (mid or HSL level) with the exception of samples from the two beaches with very high wrack biomass in the mid to upper intertidal zones (Isla Vista and East Campus; Fig. 5b). 


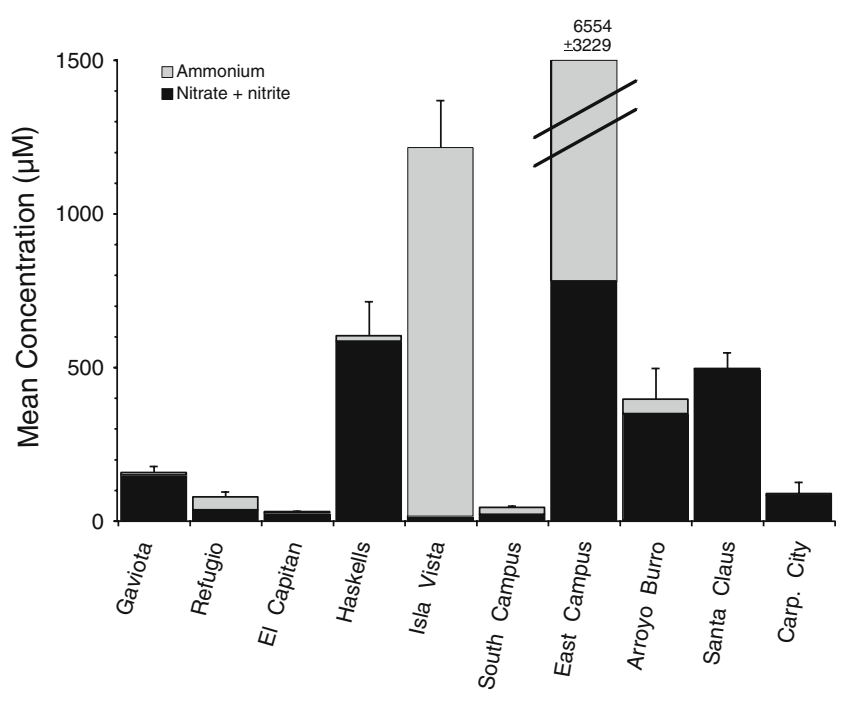

Fig. 4 Mean values of the major species of dissolved inorganic nitrogen (DIN) in pore water from the Mid or HTS intertidal level for the 10 study beaches in August 2003 ( +1 std. err., $n=3$ )

Mean intertidal pore water DIN concentrations were substantially higher $(>25 \times)$ than concentrations in the surf zone, which were generally $<2 \mu \mathrm{M}$, exceeding that at only four beaches with a peak value of $4.36 \mu \mathrm{M}$ at East Campus

Table 1 Results ( $F$ ratios) of two-way ANOVA on the effect of site (10 levels fixed) and sample level (four levels, fixed) on $\log (x+1)$ transformed concentrations of nutrients in pore water or surf zone water

\begin{tabular}{|c|c|c|c|c|}
\hline Nutrient species & SS & $d f$ & MS & $F$ \\
\hline \multicolumn{5}{|l|}{ Nitrate + nitrite } \\
\hline Site & 8.43 & 9 & 0.94 & $6.83 * * *$ \\
\hline Sample level & 76.25 & 3 & 25.42 & $185.43 * * *$ \\
\hline Site $\times$ sample level & 12.08 & 25 & 0.48 & $3.53 * * *$ \\
\hline \multicolumn{5}{|l|}{ Ammonium } \\
\hline Site & 21.14 & 9 & 2.35 & $29.46 * * *$ \\
\hline Sample level & 21.28 & 3 & 7.09 & $88.95 * * *$ \\
\hline Site $\times$ sample level & 26.05 & 25 & 1.04 & $13.07 * * *$ \\
\hline \multicolumn{5}{|l|}{ Total DIN } \\
\hline Site & 13.16 & 9 & 1.46 & $21.88 * * *$ \\
\hline Sample level & 53.74 & 3 & 17.91 & $267.99 * * *$ \\
\hline Site $\times$ sample level & 17.41 & 25 & 0.70 & $10.42 * * *$ \\
\hline \multicolumn{5}{|l|}{ Total DON } \\
\hline Site & 26.96 & 9 & 2.99 & $11.31 * * *$ \\
\hline Sample level & 1.17 & 3 & 0.39 & 1.47 \\
\hline Site $\times$ sample level & 17.47 & 25 & 0.70 & $2.64 * * *$ \\
\hline \multicolumn{5}{|l|}{ Phosphate } \\
\hline Site & 2.84 & 9 & 0.32 & $8.58 * * *$ \\
\hline Sample level & 13.31 & 3 & 4.44 & $120.64 * * *$ \\
\hline Site $\times$ sample level & 5.62 & 25 & 0.23 & $6.11 * * *$ \\
\hline
\end{tabular}

${ }^{*} p \leq 0.05,{ }^{* *} p \leq 0.01, * * * p \leq 0.001$
(Fig. 5ab). However, mean concentrations of DIN in the surf zone were positively correlated with mean concentrations of intertidal DIN at the HTS and the HSL $(p<0.01)$.

Mean concentrations of DON in pore water also varied over two orders of magnitude among beaches and sampling levels ( $7 \mu \mathrm{M}$ to $2,006 \mu \mathrm{M}$; Fig. 6). Concentrations were in the same general range as DIN values, exceeding $300 \mu \mathrm{M}$ at two beaches. Two-way analysis of variance indicated that concentrations of DON in pore water varied significantly with site but not with sample level; however, there was a significant site $\times$ sample level interaction present (Table 1). In one-way comparisons, DON concentrations varied significantly among beaches at two intertidal levels (Table 2). Mean values for DON concentrations were significantly correlated with mean intertidal DIN concentrations at all sampling levels (HTS, Mid, HSL $-p<0.01$ ).

Variation in DON concentrations with sampling level was less evident than observed for DIN with significant variation among levels found at only five of the study beaches (Table 3 ). In addition, the highest mean concentration of DON observed in intertidal pore water was lower or very similar to the surf zone concentration at six of the beaches (Fig. 6). Mean concentrations of DON in surf zone water were considerably higher than DIN values, with all values $>20 \mu \mathrm{M}$ (range $=22.7$ to $75.2 \mu \mathrm{M}$ ) and were not correlated with intertidal concentrations of DON.

Mean concentrations of phosphate in pore water were generally $<20 \mu \mathrm{M}$ but varied over an order of magnitude among beaches and levels (range $=1.8 \mu \mathrm{M}$ to $140.3 \mu \mathrm{M}$ ). These may represent underestimates of phosphate concentrations because of our use of collection methods that were not oxygen free, an effect related to the presence of reduced iron (Fe II) which oxidizes to Fe III and scavenges phosphate. The magnitude of this effect would be expected to vary depending on the amount of reduced iron in pore water and the redox status of intertidal sands, neither of which were measured. Although two-way analysis of variance indicated that concentrations of phosphate in pore water varied significantly with site and with sample level, there was a significant site $\times$ sample level interaction present (Table 1). In one-way comparisons, phosphate concentrations varied significantly among beaches at two of the intertidal levels (HTS, HSL) and in the surf zone (Table 2). Mean concentrations that exceeded $100 \mu \mathrm{M}$ were found in two samples from the HTS and mid-intertidal levels, respectively, at Isla Vista (111.8 \pm $18.5 \mu \mathrm{M})$ and East Campus $(140.3 \pm 225.3 \mu \mathrm{M})$ beaches where wrack accumulations were very high. Mean concentrations at the HSL level were generally lower $(<11 \mu \mathrm{M})$ than at higher intertidal levels, except at East Campus beach $(32 \pm 22.8 \mu \mathrm{M})$. Mean concentrations of phosphate in surf zone samples were always $<1.0 \mu \mathrm{M}$, ranging from $0.38 \mu \mathrm{M}$ to $0.82 \mu \mathrm{M}$. Concentrations of phosphate in pore water varied significantly with sampling level at all study beaches, 
Table 2 Results ( $F$ ratios) of one-way ANOVA on the effects of sample level on log $(x+1)$ transformed data of concentrations of dissolved inorganic and organic nitrogen and phosphate in pore water among study beaches

\begin{tabular}{lccccc}
\hline Sample level & Nitrate+nitrite & Ammonium & Total DIN & DON & Phosphate \\
\hline Surf & 0.37 & $2.84^{*}$ & 1.99 & 1.35 & $4.17^{* *}$ \\
HSL & $9.13^{* * *}$ & $56.59^{* * *}$ & $39.06^{* * *}$ & $3.70^{* *}$ & 20 \\
Mid & 2.16 & $31.10^{* * *}$ & $13.54^{* * *}$ & $12.01^{* * *}$ & $2.66^{* * *}$ \\
HTS & $11.28^{* * *}$ & $2.81^{*}$ & $12.00^{* * *}$ & 2.00 & 2.05 \\
\hline
\end{tabular}

HSL high swash level, Mid between HSL and HTS, HTS high tide strand or drift line

${ }^{*} p \leq 0.05,{ }^{* *} p \leq 0.01,{ }^{* * *} p \leq 0.001$

except East Campus (Table 3). Mean phosphate concentrations were correlated with mean DIN concentrations at the HTS $(p<0.005)$ and the HSL $(p<0.001)$ levels but not with DON concentrations.

Dissolved Nutrients and Macrophyte Wrack

Intertidal concentrations of DIN and DON in pore water were positively correlated $(p<0.001)$ with the total biomass of brown macroalgal wrack present on each transect (Fig. 7) as well as with the total biomass of marine macrophyte wrack $(p<0.001)$. Mean intertidal concentrations of phosphate were also correlated with the biomass of brown macroalgal wrack $(p<0.001)$.

Mean concentrations of DIN in the surf zone were positively correlated $(p<0.005)$ with the mean values of biomass of brown macroalgal wrack (Fig. 7), as were mean values of $\mathrm{NO}_{\mathrm{x}}{ }^{-} \mathrm{N}$ and of $\mathrm{NH}_{4}{ }^{+}-\mathrm{N}(p<0.02)$. However, mean DON concentrations in the surf zone were not correlated with wrack biomass (Fig. 8).

\section{Discussion}

The input rates of drift macrophytes from nearshore reefs and kelp forests to beaches measured in late summer were high $\left(>500 \mathrm{~kg}\right.$ myear $\left.^{-1}\right)$ representing a major source of organic material to beach ecosystems. This large organic subsidy results in the intertidal accumulation of macrophyte wrack, dominated by giant kelp, on beaches bordering the Santa Barbara Channel. The high concentrations of DIN, primarily nitrate, and DON found in saline intertidal pore water indicate these beaches can accumulate nitrogen in the summer (e.g., Cockcroft and McLachan 1993). The positive correlations between the standing stocks of marine macroalgal wrack and concentrations of dissolved $\mathrm{N}$ in saline intertidal pore water and surf zone water in late summer, when terrestrial groundwater inputs were very low or absent, suggested that this high detrital loading is subsequently re-mineralized in beach sand and may enhance the availability of nutrients to primary producers in nearshore waters, thus representing a potentially significant ecosystem function of open coast sandy beaches.

The high concentrations of dissolved inorganic nitrogen in saline beach pore water found in our study were generally comparable to values reported from the few existing studies of individual beaches with high macrophyte inputs (Koop and Lucas 1983; McGwynne et al. 1988), but are considerably higher than values reported for beaches where detrital inputs are dominated by phytoplankton (8$12 \mu \mathrm{M}$, see Anschutz et al. 2009; Rauch et al. 2008). Where fresh groundwater of terrestrial origin is transported
Table 3 Results ( $F$ ratios) of one-way ANOVA on the effects of sampling site on $\log (x+1)$ transformed data of concentrations of dissolved inorganic and organic nitrogen in pore water $(d f=8)$

\begin{tabular}{lccrrr}
\hline Site & Nitrate+nitrite & Ammonium & Total DIN & DON & Phosphate \\
\hline Gaviota & $184.63^{* * *}$ & $9.90^{* *}$ & $39.96^{* * *}$ & 1.83 & $75.87 * * *$ \\
Refugio & $25.70^{* * *}$ & $251.77^{* * *}$ & $106.01^{* * *}$ & 0.63 & $118.86^{* * *}$ \\
El Capitan & $65.69^{* * *}$ & $5.22^{*}$ & $69.95^{* * *}$ & 0.59 & $179.69^{* * *}$ \\
Haskells & $34.41^{* * *}$ & $8.55^{* *}$ & $41.07^{* * *}$ & 2.30 & $74.62^{* * *}$ \\
Isla Vista & $12.72^{* *}$ & $28.95^{* *}$ & $16.60^{* * *}$ & $12.62^{* *}$ & $403.37 * * *$ \\
South Campus & $101.93^{* * *}$ & $18.47^{* * *}$ & $101.54^{* * *}$ & 0.65 & $14.40^{* * *}$ \\
East Campus & $6.29^{*}$ & $33.47^{* * *}$ & $52.08^{* * *}$ & $18.23^{* * *}$ & 3.39 \\
Arroyo Burro & $65.75^{* * *}$ & $5.49^{*}$ & $80.56^{* * *}$ & $11.95^{* *}$ & $50.66^{* * *}$ \\
Santa Claus & $55.84^{* * *}$ & $54.78^{* * *}$ & $187.99^{* * *}$ & $8.95^{* *}$ & $83.18^{* * *}$ \\
Carpinteria City & $24.10^{* * *}$ & $57.06^{* * *}$ & $15.60^{* * *}$ & $10.39^{* * *}$ & $235.73 * * *$ \\
\hline
\end{tabular}

${ }^{*} p \leq 0.05, * * p \leq 0.01, * * * p \leq$ 0.001

$* p \leq 0.05, * * p \leq 0.01, * * * p \leq$
0.001


Fig. 5 Mean concentrations (+1 std. dev.) of dissolved inorganic nitrogen (DIN) in intertidal pore water from different intertidal beach levels and the surf zone for the 10 study beaches in August 2003. a Nitrate+nitrite, b ammonium
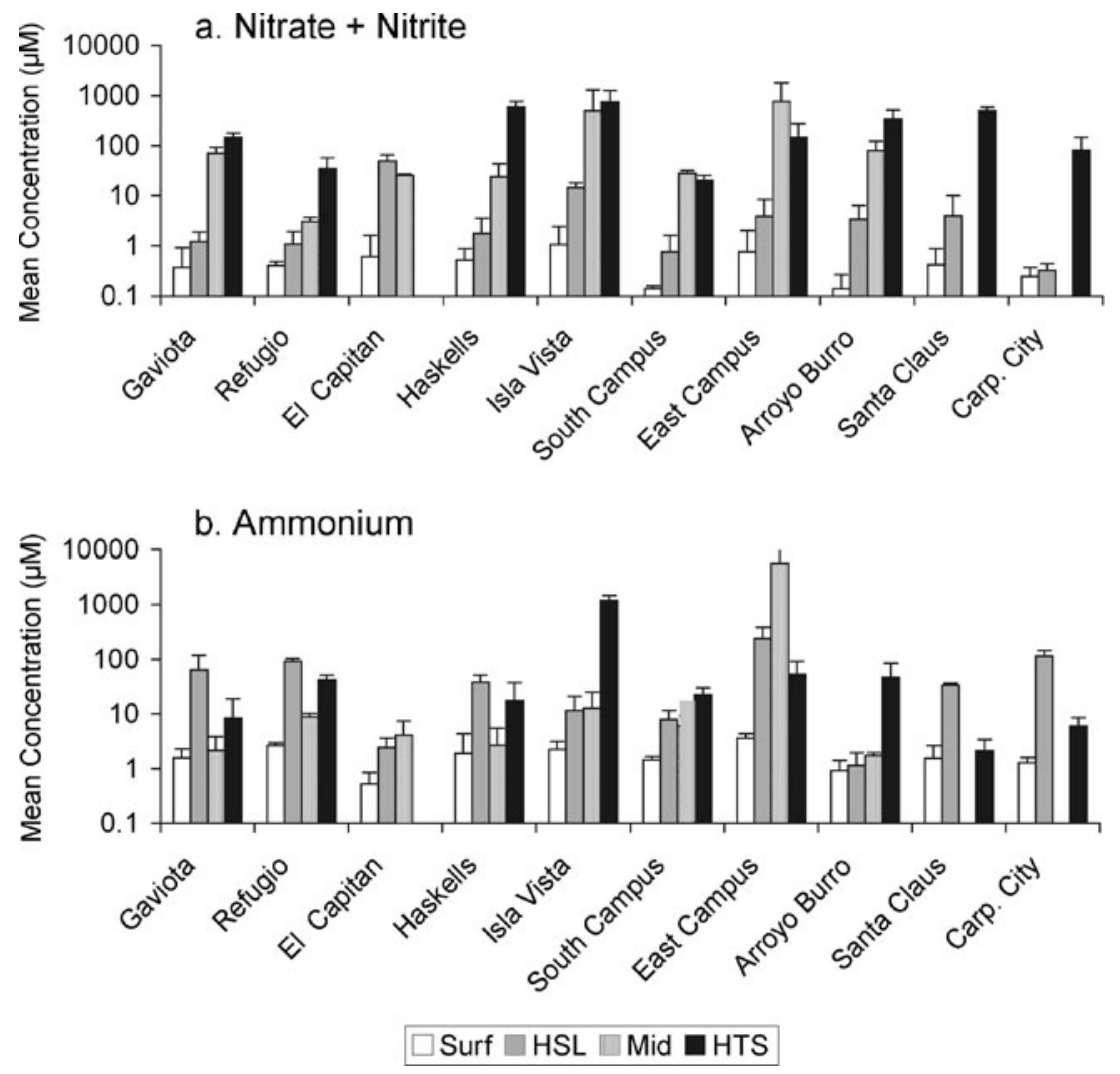

through the porous sand of beaches, nitrate concentrations of 100 to $400 \mu \mathrm{M}$ been reported in beach groundwater wells (e.g., Loveless and Oldham 2010; Maier and Pregnall 1990; Santoro et al. 2006; Swarzenski and Izbicki 2009). Dissolved nitrogen concentrations in pore water at our beaches were generally lower than values reported for estuarine groundwater affected by agricultural runoff in the study area (e.g., nitrate 1,430 to $5,400 \mu \mathrm{M}$, ammonium 4 to $249 \mu \mathrm{M}$, Page 1995) although the peak intertidal DIN concentrations we observed on beaches were comparable. Concentrations of DIN in beach pore water were considerably higher than nearshore ocean water in the vicinity of our study beaches where, for example, background nitrate concentrations can be $<1$ to $2 \mu \mathrm{M}$, increasing up to $12 \mu \mathrm{M}$ in surface waters during mesoscale eddy activity (Bassin et al. 2005) and up to $20 \mu \mathrm{M}$ during wind-driven coastal upwelling (McPhee-Shaw et al. 2007).

The highest concentrations of DIN in intertidal beach pore water were generally found in samples collected in the vicinity of the high tide strand line or drift line where wrack accumulation and invertebrate consumer activity is highest. This result supports the idea that this intertidal zone may be a key area for biogeochemical processing and transformation of subsidies of organic material cast up on the beach. Swarzenski and Izbicki (2009) also noted higher DIN concentrations (average $176 \mu \mathrm{M}$ ) in a beach monitoring
Fig. 6 Mean concentrations $(+1$ std. dev.) of dissolved organic nitrogen (DON) in intertidal pore water from different intertidal beach levels and the surf zone for the 10 study beaches in August 2003. Note-interpretation of the analyses of samples from at two of the beaches with the highest intertidal DIN values were not possible due to large negative DON values obtained

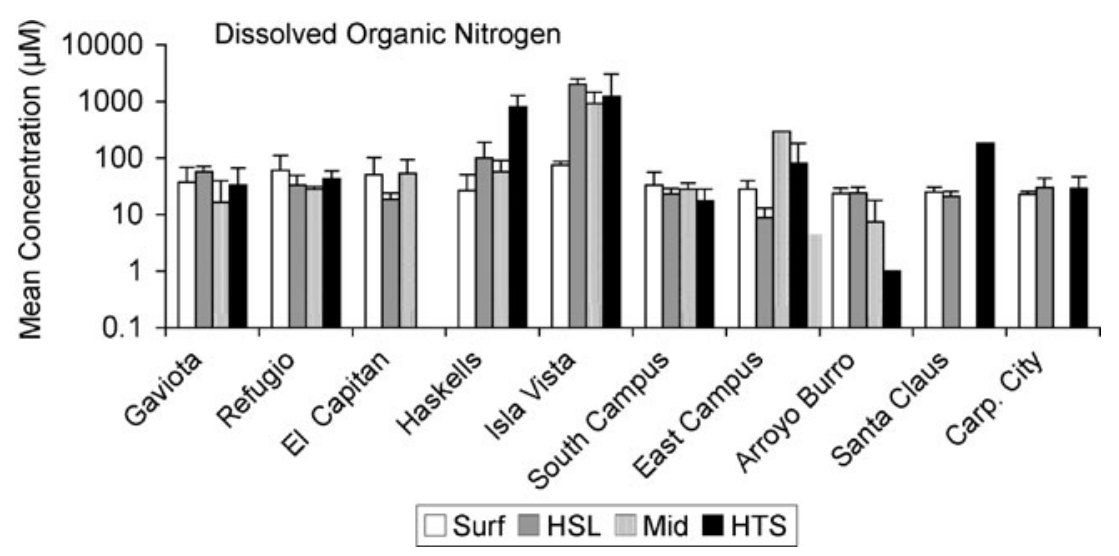




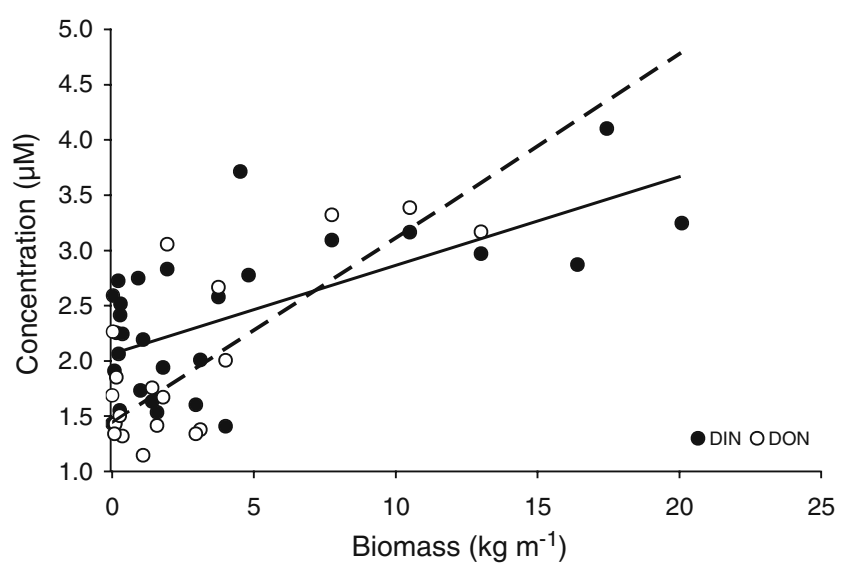

Fig. 7 Relationships between the wet biomass (standing stock) of brown macroalgal wrack and the $\log (x+1)$ transformed concentrations of DIN (solid symbols and line) and DON (open symbols and dashed line) in samples of intertidal beach pore water on each transect for the 10 study beaches in August 2003 (DIN-y $=0.080 x+2.06$, $\left.r^{2}=0.421, p<0.001 ; \mathrm{DON}-y=0.167+1.44, r^{2}=0.556, p<0.001\right)$

well located in the vicinity of the intertidal wrack line than in wells located either inland or seaward of the wrack line (averages $=39$ to $86 \mu \mathrm{M}$ ). However, McGwynne et al. (1988) found the opposite pattern for steep beaches where the wrack deposits accumulated lower on the shore.

To explore the scale of the subsidy of nitrogen to beach ecosystems from marine macrophytes and provide values for comparison, we estimated the nitrogen exported from giant kelp forests and delivered to sandy beaches as wrack. Using wrack input rates measured directly on the South Campus study beach in late summer (Fig. 2) and adjusted for loss due to consumption by detritivores (Lastra et al. 2008), the input of the dominant wrack species, M. pyrifera, to this beach would exceed 500 wet $\mathrm{kg} \mathrm{m}^{-1}$ year ${ }^{-1}$. We suggest this value

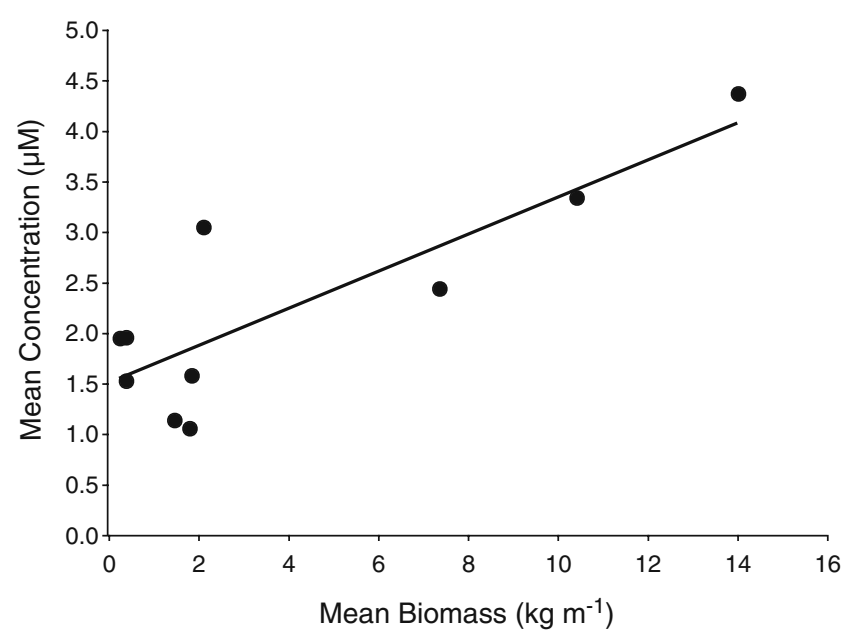

Fig. 8 Relationship between the mean wet biomass (standing stock) of brown macroalgal wrack and the mean $\log (x+1)$ transformed concentration of DIN in surf zone water for the 10 study beaches in August $2003\left(y=0.184 x+1.508, r^{2}=0.710, p<0.005\right)$ is likely a considerable underestimate as macrophyte wrack input rates were measured in summer when wave energy is low and seasonal peaks in wrack abundance on beaches generally occur in the fall in the study area (Revell et al. 2011). A dry mass input of $50 \mathrm{~kg} \mathrm{~m}^{-1}$ year ${ }^{-1}$ was estimated using a 10:1 ratio for wet/dry weight for $M$. pyrifera (Reed et al. 2008). Using a median value of $2 \% \mathrm{~N}$ for giant kelp (Reed et al. 2008), we estimated an input of $1 \mathrm{~kg} \mathrm{~N}$ $\mathrm{m}^{-1}$ year $^{-1}$ or $~ 71.4 \mathrm{~mol} \mathrm{Nm}^{-1}$ year $^{-1}$ for the South Campus study beach, a beach with fairly high, but not the highest wrack abundance for the study area in 2003 (see Fig. 3). This conservative value is comparable to the $1.4 \mathrm{~kg} \mathrm{~N}$ $\mathrm{m}^{-1}$ year $^{-1}$ reported by McLachlan and McGwynne (1986) for red macroalgal wrack and but lower than the $4.4 \mathrm{~kg} \mathrm{~N}$ $\mathrm{m}^{-1}$ year ${ }^{-1}$ reported for kelps by Koop et al. (1982).

High levels of $\mathrm{NO}_{\mathrm{x}}{ }^{-} \mathrm{N}$ in beach pore water suggest rapid nitrification of the $\mathrm{NH}_{4}{ }^{+}-\mathrm{N}$ derived from re-mineralized wrack and/or sufficient residence time for this process to occur. Residence times ranging from 12 to $24 \mathrm{~h}$ were estimated for water in beaches (McLachlan and McGwynne 1986), which is likely sufficient for $\mathrm{NH}_{4}{ }^{+} \mathrm{N}$ to be nitrified to $\mathrm{NO}_{3}{ }^{-} \mathrm{N}$. High levels of DON present at some of the study beaches could either result from active decomposition and the generation of soluble organic $\mathrm{N}$ compounds, or the DON could be composed of more recalcitrant material with a long residence time in situ. McLachlan and McGwynne (1986) estimated that up to $77 \%$ of the $\mathrm{N}$ in beach pore water was DON, suggesting perhaps that it is somewhat recalcitrant.

Acting as shallow unconfined aquifers, sandy beaches are hydraulically connected to the nearshore ocean. The hydraulic heads of these aquifers are generally maintained above sea level (Horn 2002), creating the potential for discharge to the swash and surf zone; the rate of discharge is related to the height of the water table and the permeability of the beach sand (rates $=0.0001$ to $0.01 \mathrm{~m}$ $\mathrm{h}^{-1}$; McLachlan 1989). Dissolved nutrients accumulated in this water table, as reported here, could be transported to nearshore waters both by regular tidal forcing and drainage and during erosive events. The correlations we detected between the inorganic nitrogen concentrations in wellmixed surf zone water and both intertidal DIN concentrations and macroalgal wrack biomass in late summer suggest substantial release of dissolved nutrients from intertidal pore water through tidal drainage. The interaction of tidal forcing/drainage, sediment dynamics, and erosive events will strongly affect release and transport of dissolved nutrients from beach aquifers, as will interactions with terrestrial groundwater sources when present. Given the large seasonal changes in beach widths and sand volumes characteristic of the study area (Revell et al. 2011) and the regular occurrence of a seasonal minima in beach sand levels in the spring months (Hubbard and Dugan 2003), we 
expect high temporal variability in the detrital loading, nutrient processing, and subsequent availability of wrackderived dissolved nutrients to nearshore waters. To evaluate the relative importance of this source of nutrients to nearshore waters and primary producers, further study of biogeochemical processing, the dynamics of release, and the realized transport rates of dissolved nutrients from the shallow unconfined aquifers of sandy beaches to the nearshore ocean through porous beach sand is needed.

Land-water interfaces have been proposed as biogeochemical hotspots resulting from the convergence of aquatic and terrestrial resources (McClain et al. 2003). Located at the boundaries of terrestrial and marine ecosystems, evidence is accruing that the intertidal zones of beaches fit this concept for nutrient cycling (Anschutz et al. 2009; Avery et al. 2008). Wrack deposits on beaches were shown to be metabolic hot spots with high activity and rates of $\mathrm{CO}_{2}$ flux relative to other marine and terrestrial communities (Coupland et al. 2007). We suggest that further examination of nutrient dynamics of beaches subsidized by high macrophyte wrack inputs is likely to expand the appreciation of tidal sands as important sites of biogeochemical transformation, including decomposition and trace gas emissions: active mineralization and denitrification in a saturated environment that could encourage denitrification and $\mathrm{N}_{2} \mathrm{O}$ emissions when low oxygen conditions are present or in oxygenated conditions as shown for sandy sediments on the continental shelf by Vance-Harris and Ingall (2005), for permeable wave affected coastal areas by Gihring et al. (2010) and suggested by molecular evidence from sandy beaches by Santoro et al. (2006).

We also suggest the role of mobile macrofaunal consumers may be relatively important to the breakdown and processing of phytodetritus for beaches that receive large subsidies of macroalgal wrack compared with other sedimentary habitats (e.g., Griffiths and Stenton-Dozey 1981; Lastra et al. 2008). These abundant consumers on sandy beaches, frequently talitrid amphipods (>90,000 ind $\mathrm{m}^{-1}$ of shoreline) but other taxa including isopods, coleopterans, and dipterans may be important, rapidly shredding freshly stranded macroalgal wrack which likely enhances decomposition, microbial activity, and re-mineralization.

Our results provide additional evidence of the potential significance of the function of beach ecosystems in nearshore nutrient cycling suggested by both early workers (Pearse et al. 1942) and a growing number of recent studies (Anschutz et al. 2009; Avery et al. 2008; Boudreau et al. 2001). Beaches can function as biogeochemically active filters through which terrestrial groundwater containing nutrients are transformed as they are transported to nearshore waters (e.g., Boehm et al. 2004, 2006; Loveless and Oldham 2009; Maier and Pregnall 1990; Ueda et al.
2003) and as sites of active biogeochemical processing of accumulated organic matter from pelagic marine subsidies (Burnett et al. 2003; Rauch and Denis 2008; Rauch et al. 2008). The very high inputs of organic matter and nitrogen in the form of macroalgal wrack to beach ecosystems and the positive relationship between pore water nutrient loads and the standing stock of wrack biomass reported here strongly support the concept of potentially high turnover and re-mineralization rates for imported organic matter in porous sediments. For beaches, this concept has been primarily examined to date with regard to the effects of phytoplankton blooms on intertidal nutrient flux (Anschutz et al. 2009; Rauch et al. 2008). The input of detrital subsidies to beach ecosystems in regions where macroalgal production, particularly kelps, is high combined with wave and tidal action and the potential for the rapid re-mineralization of nitrogen in porous intertidal beach sediments may in fact represent a new endpoint for the turnover of organic matter in marine sediments.

Our results suggest that the unique combination of high organic inputs and permeable sediments subject to regular tide and wave action represented by these open coast beach ecosystems along with the activity of intertidal consumers and microbial communities results in the processing and re-mineralization of substantial organic inputs in the form of drift marine macrophytes and the accumulation of high concentrations of dissolved nutrients that are subsequently available to nearshore waters and primary producers. Although these dissolved nutrients from subsidized beach ecosystems may not reach the primary donor ecosystem of giant kelp forests, they are very likely exported to shallow water and intertidal kelps and seagrasses (e.g., E. menziesii and Phyllospadix spp.) providing nutrients largely derived from kelp forests to inshore primary producers. Porous intertidal beach sands appear to function as important sites of nutrient re-mineralization and biogeochemical transformation of organic matter exported by kelp forests and reefs to the shoreline and as sources of wrack-derived nutrients to nearshore primary producers, thus potentially playing a larger role in coastal nitrogen cycling and supply than has been generally appreciated.

Acknowledgments We thank Diane Chakos, Anya Engen, Matthew James, Melissa Lippincott, Jennifer Tarmann, and Natalie Wenger for their dedication and enthusiastic assistance during the field collections and surveys, and with analyses of samples in the laboratory. We are particularly grateful to William Clinton, Allen Doyle, and Michael Weintraub for providing their expertise and assisting with nutrient analyses. This research was supported by the Santa Barbara Coastal LTER funded by the National Science Foundation (Award nos. OCE-9982105 and OCE-0620276) and by funding from the California Sea Grant Program Project \#R/CZ-174 under NOAA Grant \#NA06RG0142 through the NOAA's National Sea Grant College Program, U.S. Department of Commerce. The 
statements, findings, conclusions, and recommendations are those of the authors and do not necessarily reflect the views of the National Science Foundation, California Sea Grant, NOAA, or the U.S. Department of Commerce.

Conflict of Interest Notification The authors hereby state that they do not have a financial relationship with the organization that sponsored the research and that no potential conflicts of interest exist to our knowledge and understanding. We maintain full control of all primary data and we agree to allow the journal to review our data if requested.

Open Access This article is distributed under the terms of the Creative Commons Attribution Noncommercial License which permits any noncommercial use, distribution, and reproduction in any medium, provided the original author(s) and source are credited.

\section{References}

Anderson, W.B., and G.A. Polis. 1999. Nutrient fluxes from water to land: Seabirds affect plant nutrient status on Gulf of California islands. Oecologia 118(3): 324-332.

Anschutz, P., T. Smith, A. Mouret, J. Deborde, S. Bujan, D. Poirier, and P. Lecroart. 2009. Tidal sands as biogeochemical reactors. Estuarine, Coastal and Shelf Science 84: 84-90.

Avery Jr., G.B., R.J. Kieber, and K.J. Taylor. 2008. Nitrogen release from surface sand of a high energy beach along the southeastern coast of North Carolina, USA. Biogeochemistry 89: 357-365.

Bascom, W. 1980. Waves and beaches. New York: Anchor.

Bassin, C.J., L. Washburn, M.A. Brzezinski, and E.E. McPhee-Shaw. 2005. Sub-mesoscale coastal eddies observed by high frequency radar: A new mechanism for delivering nutrients to kelp forests in the Southern California Bight. Geophysical Research Letters 32: L12604.

Berelson, W.M., D. Heggie, A. Longmore, T. Kilgore, G. Nicholson, and G. Skyring. 1998. Benthic nutrient recycling in Port Phillip Bay, Australia. Estuarine, Coastal and Shelf Science 46: $917-$ 934.

Boehm, A.B., G.G. Shellenbarger, and A. Paytan. 2004. Groundwater discharge: Potential association with fecal indicator bacteria in the surf zone. Environmental Science \& Technology 38: 35593566 .

Boehm, A.B., A. Paytan, G.G. Shellenbarger, and K.A. Davis. 2006. Composition and flux of groundwater from a California beach aquifer: Implications for nutrient supply to the surf zone. Continental Shelf Research 26: 269-282.

Boudreau, B.P., M. Huettel, S. Forster, R.A. Jahnke, A. McLachlan, J. J. Middelburg, P. Nielsen, F. Sanone, G. Taghon, W. Van Raaphorst, I. Webster, J.M. Weslawski, P. Wiberg, and B. Sundby. 2001. Permeable marine sediments: Overturning an old paradigm. Eos, Transactions, American Geophysical Union 82 (11): 133-137.

Boyer, K.E., and P. Fong. 2005. Macroalgal-mediated transfers of water column nitrogen to intertidal sediments and salt marsh plants. Journal of Experimental Marine Biology and Ecology 321 (1): 59-69.

Boyle, K.A., K. Kamer, and P. Fong. 2004. Spatial and temporal patterns in sediment and water column nutrients in a eutrophic southern California estuary. Estuaries 27(3): 378-388.

Burnett, W.C., H. Bokuniewicz, M. Huettel, W.S. Moore, and M. Taniguchi. 2003. Groundwater and pore water inputs to the coastal zone. Biogeochemistry 66: 3-33.
Cockcroft, A.C., and A. McLachan. 1993. Nitrogen budget for a highenergy ecosystem. Marine Ecology Progress Series 100: 287-299.

Colombini, I., and L. Chelazzi. 2003. Influence of marine allochthonous input on sandy beach communities. Oceanography and Marine Biology. Annual Review 41: 115-159.

Coupland, G.T., C.M. Duarte, and D.I. Walker. 2007. High metabolic rates in beach cast communities. Ecosystems 10: 1341-1350.

Cowan, J.L.W., J.R. Pennock, and W.R. Boynton. 1996. Seasonal and interannual patterns of sediment-water nutrient and oxygen fluxes in Mobile Bay, Alabama (USA): Regulating factors and ecological significance. Marine Ecology Progress Series 141(1): 229-245.

Doyle, A., M.N. Weintraub, and J.P. Schimel. 2004. Digestion and simultaneous colorimetric analysis of carbon and nitrogen in soil extracts. Soil Science Society of America Journal 68: 669676.

Dugan, J.E., D.M. Hubbard, M. McCrary, and M. Pierson. 2003. The response of macrofauna communities and shorebirds to macrophyte wrack subsidies on exposed sandy beaches of southern California. Estuarine, Coastal and Shelf Science 58S: 133-148.

Dugan, J.E., D.M. Hubbard, I.F. Rodil, and D. Revell. 2008. Ecological effects of coastal armoring on sandy beaches. Marine Ecology 29: 160-170.

Gihring, T.M., A. Canion, A. Riggs, M. Huettel, and J.E. Kostka. 2010. Denitrification in shallow, sublittoral Gulf of Mexico permeable sediments. Limnology and Oceanography 55(1): 43-44.

Griffiths, C.L., and J. Stenton-Dozey. 1981. The fauna and rate of degradation of stranded kelp. Estuarine, Coastal and Shelf Science 12: 645-653.

Griffiths, C.L., J.M.E. Stenton-Dozey, and K. Koop. 1983. Kelp wrack and the flow of energy through a sandy beach ecosystem. In Sandy beaches as ecosystems, ed. A. McLachlan and T. Erasmus, 547-556. The Hague: Junk.

Hayes, W. B. 1974. Sand-beach energetics: importance of the isopod Tylos punctatus. Ecology 55(4): 838-847.

Heck Jr., K.L., T.J.B. Carruthers, C.M. Duarte, A.R. Hughes, G. Kendrick, R.J. Orth, and S.W. Williams. 2008. Trophic transfers from seagrass meadows subsidize diverse marine and terrestrial consumers. Ecosystems 11: 1198-1210.

Hobday, A. 2000. Abundance and dispersal of drifting kelp, Macrocystis pyrifera, rafts in the Southern California Bight. Marine Ecology Progress Series 195: 101-116.

Horn, D.P. 2002. Beach groundwater dynamics. Geomorphology 48: $121-146$.

Hubbard, D.M., and J.E. Dugan. 2003. Shorebird use of an exposed sandy beach in southern California. Estuarine, Coastal and Shelf Science 58S: 169-182.

Huettel, M., and A. Rusch. 2000. Transport and degradation of phytoplankton in permeable sediment. Limnology and Oceanography 45(3): 534-549.

Inglis, G. 1989. The colonisation and degradation of stranded Macrocystis pyrifera (L.) C. Ag. by the macrofauna of a New Zealand sandy beach. Journal of Experimental Marine Biology and Ecology 125: 203-217.

Jahnke, R., M. Richards, J. Nelson, C. Robertson, A. Rao, and D. Jahnke. 2005. Organic matter remineralization and porewater exchange rates in permeable South Atlantic Bight continental shelf sediments. Continental Shelf Research 25: 1433-1452.

Johnson, K.S., R.L. Petty, and J. Thomsen. 1985. Flow-injection analysis for seawater micronutrients. In Mapping strategies in chemical oceanography (Advances in Chemistry Series No. 209), ed. A. Zirino, 7-30. Washington: American Chemical Society.

Koop, K., and M.I. Lucas. 1983. Carbon flow and nutrient regeneration from the decomposition of macrophyte debris in a sandy beach microcosm. In Sandy beaches as ecosystems, ed. A. McLachlan and T. Erasmus, 249-262. The Hague: Junk. 
Koop, K., R.C. Newell, and M.I. Lucas. 1982. Microbial regeneration of nutrients from the decomposition of macrophyte debris on the shore. Marine Ecology Progress Series 9: 91-96.

Lastra, M., H.M. Page, J.E. Dugan, D.M. Hubbard, and I.F. Rodil. 2008. Processing of allochthonous macrophyte subsidies by sandy beach consumers: Estimates of feeding rates and impacts on food resources. Marine Biology 154: 163-174.

Loveless, A.M., and C.E. Oldham. 2010. Natural attenuation of nitrogen in groundwater discharging through a sandy beach. Biogeochemistry 98(1-3): 75-87. doi:10.1007/s10533-0099377-x.

Maier, C.M., and A.M. Pregnall. 1990. Increased macrophyte nitrate reductase activity as a consequence of groundwater input of nitrate through sandy beaches. Marine Biology 107: 263-271.

Mann, K.H. 2000. Ecology of coastal waters. Boston: Blackwell.

Mateo, M.A., J.L. Sanchez-Lizaso, and J. Romero. 2003. Posidonia oceanica 'banquettes': A preliminary assessment of the relevance for meadow carbon and nutrients budget. Estuarine, Coastal and Shelf Science 56: 85-90.

McCaffrey, R.J., A.C. Myers, E. Davey, G. Morrison, M. Bender, N. Luedtke, D. Cullen, P. Froelich, and G. Klinkhammer. 1980. Relation between pore water chemistry and benthic fluxes of nutrients and manganese in Narragansett Bay, Rhode Island. Limnology and Oceanography 25(1): 31-44.

McClain, M.E., E.W. Boyer, C.L. Dent, S.E. Gergel, N.B. Grimm, P. M. Groffman, S.C. Hart, J.W. Harvey, C.S. Johnston, E. Mayorga, W.H. McDowell, and G. Pinay. 2003. Biogeochemical hotspots and hot moments at the interface of terrestrial and aquatic ecosystems. Ecosystems 6: 310-312.

McGwynne, L.E., A. McLachlan, and J.P. Furstenberg. 1988. Wrack breakdown on sandy beaches-Its impact on interstitial meiofauna. Marine Environmental Research 25: 213-232.

McLachlan, A. 1989. Water filtration by dissipative beaches. Limnology and Oceanography 34: 774-780.

McLachlan, A., and A. Brown. 2006. The ecology of sandy shores, 2nd ed. London: Academic.

McLachlan, A., and L.E. McGwynne. 1986. Do sandy beaches accumulate nitrogen? Marine Ecology Progress Series 34: 191195.

McLachlan, A., A.G. Eliot, and D.J. Clarke. 1985. Water filtration through reflective microtidal beaches and shallow sublittoral sands and its implications for an inshore ecosystem in Western Australia. Estuarine, Coastal and Shelf Science 21: 91-104.

McPhee-Shaw, E.E., D.A. Siegel, L. Washburn, M.A. Brzezinski, J.L. Jones, A. Leydecker, and J.M. Melack. 2007. Mechanisms for nutrient delivery to the inner shelf: Observations from the Santa Barbara Channel. Limnology and Oceanography 52(5): 17481766.

Orr, M., M. Zimmer, D.E. Jelinski, and M. Mews. 2005. Wrack deposition on different beach types: Spatial and temporal variation in the pattern of subsidy. Ecology 86(6): 1496-1507.
Page, H.M. 1995. Influence of watershed runoff on nutrient dynamics in a southern California salt marsh. Estuarine, Coastal and Shelf Science 41: 163-180.

Pearse, A.S., H.J. Humm, and G.W. Wharton. 1942. Ecology of sand beaches at Beaufort, NC. Ecological Monographs 12(2): 135190.

Polis, G.A., and S.D. Hurd. 1996. Linking marine and terrestrial food webs: Allochthonous input from the ocean supports high secondary productivity on small islands and coastal land communities. The American Naturalist 147(3): 396-423.

Rauch, M., and L. Denis. 2008. Spatio-temporal variability in benthic mineralization processes in the eastern English Channel. Biogeochemistry 89: 163-180.

Rauch, M., L. Denis, and J.C. Dauvin. 2008. The effects of Phaeocystis globosa bloom on the dynamics of the mineralization processes in intertidal permeable sediment in the eastern English Channel (Wimereux, France). Marine Pollution Bulletin 56: 1284-1293.

Reed, D.C., A. Rassweiler, and K.K. Arkema. 2008. Biomass rather than growth rate determines variation in net primary production by giant kelp. Ecology 89(9): 2493-2505.

Revell, D.L., J.E. Dugan, and D.M. Hubbard. 2011. Physical and ecological responses to the 1997-98 El Nino. Journal of Coastal Research 27, (in press).

Rocha, C. 2008. Sandy sediments as active biogeochemical reactors: Compound cycling in the fast lane. Aquatic Microbial Ecology 53: 119-127.

Rowe, G.T., C.H. Clifford, and K.L. Smith. 1975. Benthic nutrient regeneration and its coupling to primary productivity in coastal waters. Nature 255: 215-217.

Rusch, A., M. Huettel, C. Wilds, and C.E. Reimers. 2006. Benthic oxygen consumption and organic matter turnover in organicpoor, permeable shelf sands. Aquatic Geochemistry 12: 1-19.

Santoro, A.E., A.B. Boehm, and C.A. Francis. 2006. Denitrifier community composition along a nitrate and salinity gradient in a coastal aquifer. Applied and Environmental Microbiology 72: 2102-2109.

Swarzenski, P.W., and J.A. Izbicki. 2009. Coastal groundwater dynamics off Santa Barbara, California: Combining geochemical tracers, electromagnetic seepmeters and electrical resistivity. Estuarine, Coastal and Shelf Science 83: 77-89.

Ueda, S., C.U. Go, M. Suzumura, and E. Sumi. 2003. Denitrification in a seashore sandy deposit influenced by groundwater discharge. Biogeochemistry 63: 187-205.

Vance-Harris, C., and E. Ingall. 2005. Denitrification pathways and rates in the sandy sediments of the Georgia continental shelf, USA. Geochemical Transactions 6: 12-18.

Wenner, A.M., Y.O. Ricard, and J.E. Dugan. 1987. Hippid crab population structure and food availability on Pacific shorelines. Bulletin of Marine Science 41(2): 221-233.

ZoBell, C.E. 1971. Drift seaweeds on San Diego County beaches. Beihefte Nr. zur Nova Hedwigia 32: 269-314. 